\title{
Genetic differentiation and post-glacial establishment of the geographical distribution in Aegilops caudata $\mathrm{L}$.
}

\author{
Shoji Ohta \\ Department of Bioscience, Fukui Prefectural University, Kenjojima, Matsuoka, \\ Yoshida, Fukui 910-1195, Japan
}

(Received 8 June 2000, accepted 25 July 2000)

\begin{abstract}
Aegilops caudata L. is a diploid wild relative of wheat distributed over the northeastern Mediterranean from Greece to northern Iraq. To elucidate the geographical differentiation pattern, 35 accessions derived from the entire distribution area were crossed with four Tester strains. Pollen fertility in the $\mathrm{F}_{1}$ hybrids varied from 0 to $96.3 \%$ among cross combinations, closely correlating with the geographical regions where the parental accessions were collected. Based on the intraspecific hybrid sterility, the present distribution area of Ae.caudata was divided into two geographical regions effectively isolated by the mountainous region lying between West Anatolia and Central Anatolia. The western region is composed of Greece and West Anatolia, while the eastern region consists of Central Anatolia, South Anatolia, East Anatolia and northern Iraq. The present results and the facts from recent palaeopalynological works suggest that during the maximum glacial period from $18000 \mathrm{BP}$ to $16000 \mathrm{BP}$, Ae. caudata occurred in the two isolated regions, i.e., the region surrounding the Aegean Sea and the western Levant or some sheltered habitats in the East Taurus / Zagros mountains arc, and that it migrated into Central and East Anatolia from the latter regions as the climate became warmer. Furthermore, it is also suggested that the Levant populations now occur in the eastern region of the distribution, while those occurring in the Aegean Sea region during the last glacial period now occupy the western region of the distribution.
\end{abstract}

\section{INTRODUCTION}

Aegilops caudata L. (syn. Ae. markgrafii (Greuter) Hammer, $2 \mathrm{n}=2 \mathrm{x}=14$ ) is an annual, wild relative of wheat distributed over the northeastern Mediterranean basin from Greece to the northern part of Iraq (Eig, 1929; Bor, 1968, 1970). Two varieties are described in this species based on spike morphology, var. typica and var. polyathera Boiss. (Eig, 1929), or Ae. markgrafii var. markgrafii and var. polyathera (Boiss.) Hammer (Hammer, 1980). They often occur sympatrically in the Aegean islands (Rechinger, 1943; Ohta, 1992). Tanaka et al. (1967) was the first to find remarked sterility in inter-varietal $F_{1}$ hybrids ( $\mathrm{F}_{1}$ 's) of Ae. caudata. Recently, however, the $\mathrm{F}_{1}$ 's between the two varieties collected from the sympatric stands on the Aegean islands were found to be fully fertile (Ohta, 1992). The author furthermore crossed nine Aegean and one Iraqi accessions with the four Tester strains collected from different geographical areas, concluded that intraspecific hybrid sterility is not specific to the varieties but correlated with the geographical areas,

Edited by Takashi Endo

* Corresponding author. E-mail: ohta@fpu.ac.jp and suggested that the distribution area of Ae. caudata can be divided into the western and the eastern regions based on the hybrid sterility. The former is composed of the Greek mainland and Aegean islands, and the latter of the Anatolian Plateau, Syria and Iraq (Ohta, 1992). The aim of the present study is to reveal the geographical differentiation pattern in Ae. caudata over its entire distribution area. Accessions collected from the entire distribution area were crossed with the four Tester strains. Based on pollen and seed fertility and chromosome pairing at the first metaphase (MI) of meiosis in the $\mathrm{F}_{1}$ 's and the parental lines, I discuss the geographical differentiation pattern and the post-glacial establishment of the geographical distribution in Ae. caudata.

\section{MATERIALS AND METHODS}

Plant materials. Collection sites and morphological varieties of the 35 accessions of Ae. caudata and the four Testers are shown in Fig. 1 and Tables 1, 2 and 3. They were collected from the entire distribution area of the species. Nine of them were collected from the Aegean islands (Sites 1 to 9), 23 from Turkey (Sites 10 to 32) and the other three from northern Iraq (Sites 33 to 35 ). They 


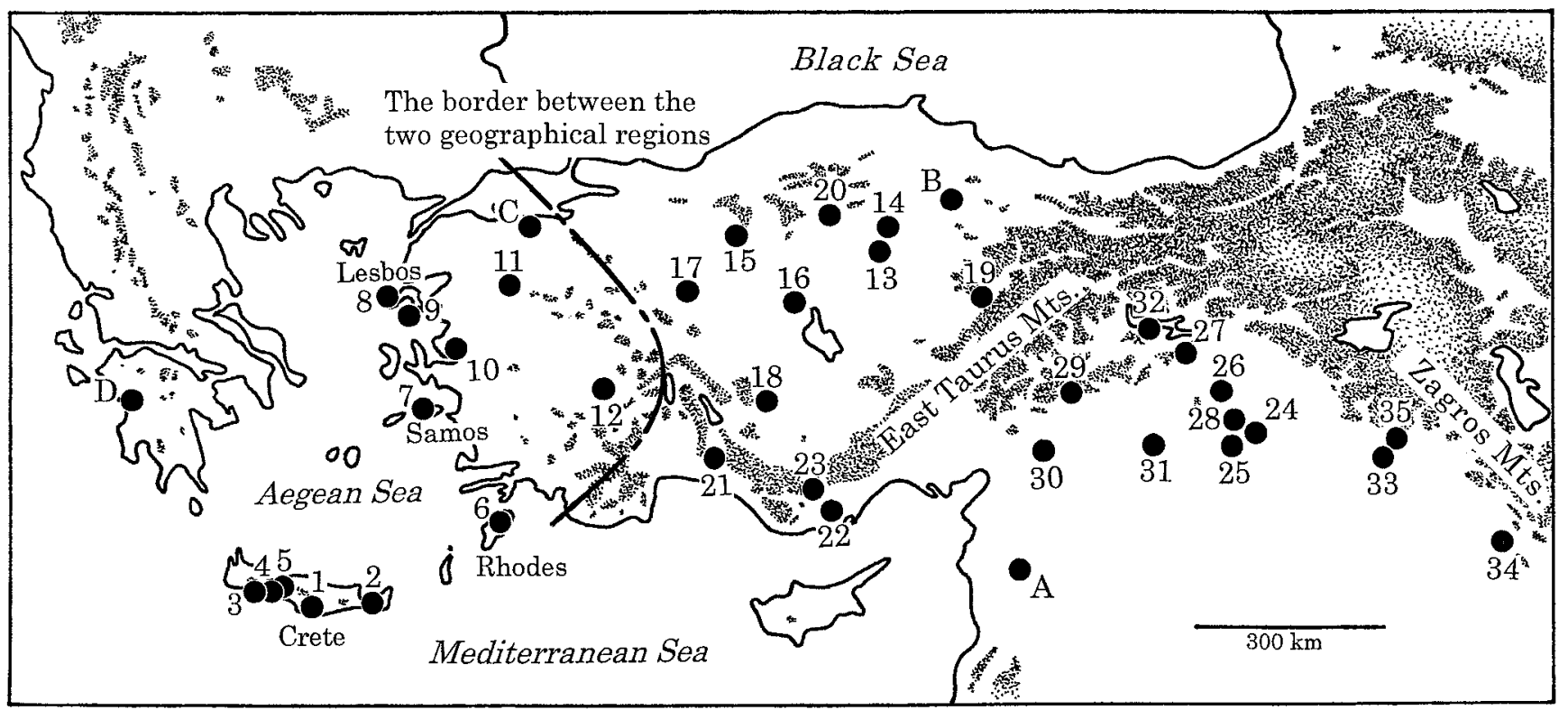

Fig. 1. Collection sites of the four Testers (A, B, C and D) and 35 accessions of Ae. caudata used in the present study. Mountainous regions higher than $1500 \mathrm{~m}$ above sea level are shadowed with dots. A broken line indicates the border between the two geographical regions defined from intraspecific hybrid sterility.

are all maintained at the Plant Germ-plasm Institute, Kyoto University and at Fukui Prefectural University. For the detailed localities of the collection sites, refer to Tanaka (1983) and Sakamoto (1986). The Turkish sites were grouped into four geographical divisions after Davis (1965). Three sites (Sites 10 to 12) were located in West Anatolia, eight (Sites 13 to 20) in Central Anatolia, three (Sites 21 to 23) in South Anatolia and nine (Sites 24 to 32) in East Anatolia. The four Tester strains were collected from peripheral localities of the distribution area (Fig. 1), and the $\mathrm{F}_{1}$ 's among them were highly sterile (Tanaka et al., 1967; Ohta, 1992).

Crossing, cultivation and cytology. The 35 accessions were hand-pollinated with the four Testers after emasculation. Parental lines and $\mathrm{F}_{1}$ 's were grown under a vinyl roof under natural day-length and temperature conditions, and they all grew vigorously to maturity. Chromosome pairing at MI in the pollen mother cells (PMCs) was examined by the aceto-carmine smear technique. To sample the pollen grains, three anthers were picked from each floret on a slide just before anthesis. Pollen grains were stained in a dilute acetocarmine solution and at least 2000 pollen grains from each slide were counted. They were classified into following five classes according to the degree of development: Empty pollen grains with no nucleus (PE), pollen grains with a nucleus (P1), with two nuclei (P2), with three nuclei but with poor starch development (P3), and normal pollen grains with three nuclei and normal starch development (PN). Two estimates were calculated for the degree of pollen normality. One was the percentage of $\mathrm{PN}$ to the total number of pollen grains observed (PPN). The other was the pollen development index (PDI) calculated as $100 \times(0 \times \mathrm{PE}+0.25 \times \mathrm{P} 1+0.5 \times \mathrm{P} 2+0.75 \times \mathrm{P} 3+1 \times \mathrm{PN})$ / the total number of pollen grains observed. A value for each class was applied arbitrarily so that the PDI ranges from 0 (all pollen grains empty) to 100 (all pollen grains normal). The PDI was adopted because the proportions of the aborted pollen grains at various developmental stages varied among the $\mathrm{F}_{1}$ 's showing a similar PPN value. The percentage of dehiscent anthers to all of the anthers examined (PDA) was also examined using the same anther samples as pollen normality. The PDA ranges from 0 (no anther dehiscent) to 100 (all anthers dehiscent). Anthers were sampled from each plant at least twice at an interval of three to seven days and the averages were calculated for the above three estimates. For the estimate of embryo-sac normality, seed set after open-pollination was examined based on the seed set on the lowest two florets of at least 10 spikes from each parent and $F_{1}$ hybrid. It was given as the percentage of the florets bearing plump seeds to the total number of florets examined. Voucher specimens are preserved at Fukui Prefectural University, the National Science Museum, Japan, and the Royal Botanic Gardens, Kew, U. K.

\section{RESULTS}

Chromosome pairing. Chromosome pairing at MI in all of the parental accessions and $\mathrm{F}_{1}$ 's was normal and seven tightly associated bivalents were formed in most 
Table 1. The estimates of pollen and seed fertility in the $\mathrm{F}_{1}$ hybrids between the four Testers and the 12 accessions of Ae. caudata from the Aegean islands and West Anatolia. PPN: percentage normal pollen grains, PDI: pollen development index, PDA: percentage dehiscent anthers, and PSS: percentage seed set

\begin{tabular}{|c|c|c|c|c|c|c|c|}
\hline \multirow[b]{2}{*}{$\begin{array}{l}\text { Site } \\
\text { No. }\end{array}$} & \multirow[b]{2}{*}{$\begin{array}{l}\text { Accession }{ }^{a)} \\
\text { No. }\end{array}$} & \multirow[b]{2}{*}{ Var. ${ }^{\text {b) }}$} & \multirow[b]{2}{*}{$\begin{array}{l}\text { Esti- } \\
\text { mates }\end{array}$} & \multicolumn{4}{|c|}{ Testers } \\
\hline & & & & $\begin{array}{c}\text { A } \\
\text { KU6-1 } \\
\text { T }\end{array}$ & $\begin{array}{c}\text { B } \\
\text { KU5852 } \\
\text { P }\end{array}$ & $\begin{array}{c}\mathrm{C} \\
\text { KU5864 } \\
\mathrm{T} \\
\end{array}$ & $\begin{array}{c}\mathrm{D} \\
\text { KU5871 } \\
\mathrm{T}\end{array}$ \\
\hline \multicolumn{8}{|c|}{ Aegean Islands } \\
\hline 1 & KU12044B & $\mathrm{P}$ & $\begin{array}{l}\text { PPN } \\
\text { PDI } \\
\text { PDA } \\
\text { PSS }\end{array}$ & $\begin{array}{l}0 \\
0 \\
0 \\
0\end{array}$ & $\begin{array}{l}0 \\
0.9 \\
0 \\
22.5\end{array}$ & $\begin{array}{c}0 \\
16.6 \\
0 \\
31.5\end{array}$ & $\begin{array}{l}25.0 \\
34.2 \\
16.7 \\
74.1\end{array}$ \\
\hline 2 & KU12055B & $\mathrm{P}$ & $\begin{array}{l}\text { PPN } \\
\text { PDI } \\
\text { PDA } \\
\text { PSS }\end{array}$ & $\begin{array}{l}0 \\
8.0 \\
0 \\
10.0\end{array}$ & $\begin{array}{l}0 \\
8.6 \\
0 \\
38.9\end{array}$ & $\begin{array}{l}14.5 \\
50.0 \\
73.3 \\
37.1\end{array}$ & $\begin{array}{l}83.5 \\
85.6 \\
90.4 \\
75.9\end{array}$ \\
\hline 3 & KU12155B & $\mathrm{P}$ & $\begin{array}{l}\text { PPN } \\
\text { PDI } \\
\text { PDA } \\
\text { PSS }\end{array}$ & $\begin{array}{l}0 \\
5.1 \\
0 \\
14.1\end{array}$ & $\begin{array}{c}0 \\
12.9 \\
0 \\
21.4\end{array}$ & $\begin{array}{l}0 \\
0.3 \\
0 \\
27.3\end{array}$ & $\begin{array}{r}69.1 \\
77.9 \\
100.0 \\
78.6\end{array}$ \\
\hline 4 & KU12162A & $\mathrm{T}$ & $\begin{array}{l}\text { PPN } \\
\text { PDI } \\
\text { PDA } \\
\text { PSS }\end{array}$ & $\begin{array}{c}0 \\
11.4 \\
0 \\
13.0\end{array}$ & $\begin{array}{c}0 \\
5.9 \\
0 \\
23.5\end{array}$ & $\begin{array}{c}0 \\
11.3 \\
0 \\
50.7\end{array}$ & $\begin{array}{l}72.2 \\
74.2 \\
76.2 \\
82.4\end{array}$ \\
\hline 5 & KU12163A & $\mathrm{T}$ & $\begin{array}{l}\text { PPN } \\
\text { PDI } \\
\text { PDA } \\
\text { PSS }\end{array}$ & $\begin{array}{l}0.1 \\
3.5 \\
0 \\
8.6\end{array}$ & $\begin{array}{c}0 \\
2.0 \\
0 \\
14.8\end{array}$ & $\begin{array}{c}0.8 \\
20.1 \\
0 \\
\text { n.o. }^{\text {c) }}\end{array}$ & $\begin{array}{l}96.3 \\
96.5 \\
95.2 \\
80.6\end{array}$ \\
\hline 6 & KU12073A & $\mathrm{T}$ & $\begin{array}{l}\text { PPN } \\
\text { PDI } \\
\text { PDA } \\
\text { PSS }\end{array}$ & $\begin{array}{l}0 \\
1.2 \\
0 \\
22.7\end{array}$ & $\begin{array}{c}0.1 \\
4.3 \\
0 \\
42.9\end{array}$ & $\begin{array}{c}0 \\
15.7 \\
0 \\
40.0\end{array}$ & $\begin{array}{l}0 \\
5.0 \\
0 \\
43.8\end{array}$ \\
\hline 7 & KU12100B & $\mathrm{P}$ & $\begin{array}{l}\text { PPN } \\
\text { PDI } \\
\text { PDA } \\
\text { PSS }\end{array}$ & $\begin{array}{c}0 \\
10.1 \\
0 \\
31.8\end{array}$ & $\begin{array}{l}15.1 \\
35.4 \\
55.6 \\
62.9\end{array}$ & $\begin{array}{l}42.6 \\
58.7 \\
71.4 \\
63.2\end{array}$ & $\begin{array}{l}86.3 \\
91.3 \\
66.7 \\
89.6\end{array}$ \\
\hline 8 & KU12117B & $\mathrm{P}$ & $\begin{array}{l}\text { PPN } \\
\text { PDI } \\
\text { PDA } \\
\text { PSS }\end{array}$ & $\begin{array}{l}0 \\
0.5 \\
0 \\
5.3\end{array}$ & $\begin{array}{l}0.1 \\
0.3 \\
0 \\
7.1\end{array}$ & $\begin{array}{r}8.9 \\
21.2 \\
28.6 \\
52.8\end{array}$ & $\begin{array}{r}56.0 \\
69.5 \\
100.0 \\
77.5\end{array}$ \\
\hline 9 & KU12121A & $\mathrm{T}$ & $\begin{array}{l}\text { PPN } \\
\text { PDI } \\
\text { PDA } \\
\text { PSS }\end{array}$ & $\begin{array}{l}0 \\
0.1 \\
0 \\
0\end{array}$ & $\begin{array}{l}0.3 \\
0.4 \\
0 \\
1.8\end{array}$ & $\begin{array}{c}0.2 \\
16.4 \\
0 \\
21.5\end{array}$ & $\begin{array}{l}0.1 \\
1.1 \\
0 \\
2.0\end{array}$ \\
\hline $\begin{array}{l}\text { West } \\
10\end{array}$ & $\begin{array}{l}\text { hatolia } \\
\text { KU11401 }\end{array}$ & $\mathrm{T}$ & $\begin{array}{l}\text { PPN } \\
\text { PDI } \\
\text { PDA } \\
\text { PSS }\end{array}$ & $\begin{array}{l}0 \\
4.2 \\
0 \\
19.2\end{array}$ & $\begin{array}{c}0 \\
10.8 \\
0 \\
16.9\end{array}$ & $\begin{array}{l}13.7 \\
59.5 \\
80.0 \\
48.2\end{array}$ & $\begin{array}{r}68.8 \\
83.2 \\
100.0 \\
91.5\end{array}$ \\
\hline 11 & KU11403 & $\mathrm{T}$ & $\begin{array}{l}\text { PPN } \\
\text { PDI } \\
\text { PDA } \\
\text { PSS }\end{array}$ & $\begin{array}{l}0 \\
6.2 \\
0 \\
7.7\end{array}$ & $\begin{array}{l}\text { n.o. } \\
\text { n.o. } \\
\text { n.o. } \\
\text { n.o. }\end{array}$ & $\begin{array}{l}22.7 \\
53.4 \\
88.9 \\
11.0\end{array}$ & $\begin{array}{c}8.9 \\
38.0 \\
0 \\
8.0\end{array}$ \\
\hline 12 & KU12169 & $\mathrm{T}$ & $\begin{array}{l}\text { PPN } \\
\text { PDI } \\
\text { PDA } \\
\text { PSS }\end{array}$ & $\begin{array}{c}0.8 \\
26.0 \\
0 \\
26.3\end{array}$ & $\begin{array}{c}0.2 \\
38.2 \\
0 \\
19.6\end{array}$ & $\begin{array}{l}20.3 \\
63.3 \\
54.2 \\
30.5\end{array}$ & $\begin{array}{l}36.9 \\
62.0 \\
92.6 \\
51.5\end{array}$ \\
\hline
\end{tabular}

${ }^{\text {a) }} \mathrm{KU}$ : Accession numbers assigned by Kyoto University.

b) Variety: $\mathrm{P}$ and $\mathrm{T}$ indicate var. polyathera and var. typica, respectively.

c) n.o.: no observation. 
Table 2. The estimates of pollen and seed fertility in the $\mathrm{F}_{1}$ hybrids between the four Testers and the eight accessions of Ae. caudata from Central Anatolia. For the abbreviations of estimates and varieties, see Table 1

\begin{tabular}{|c|c|c|c|c|c|c|c|}
\hline \multirow[b]{2}{*}{$\begin{array}{l}\text { Site } \\
\text { No. }\end{array}$} & \multirow{2}{*}{$\begin{array}{l}\text { Accession } \\
\text { No. }\end{array}$} & \multirow[b]{2}{*}{ Var. } & \multirow{2}{*}{$\begin{array}{l}\text { Esti- } \\
\text { mates }\end{array}$} & \multicolumn{4}{|c|}{ Testers } \\
\hline & & & & $\mathrm{A}$ & B & $\mathrm{C}$ & $\mathrm{D}$ \\
\hline \multirow[t]{4}{*}{13} & KU5853 & $\mathrm{P}$ & PPN & 0 & 17.8 & 0 & n.o. \\
\hline & & & PDI & 19.6 & 54.9 & 1.1 & n.o. \\
\hline & & & PDA & 0 & 23.3 & 0 & n.o. \\
\hline & & & PSS & 12.5 & 29.2 & 0.6 & n.o. \\
\hline \multirow[t]{4}{*}{14} & KU5854 & $\mathrm{P}$ & PPN & n.o. & 51.8 & 0 & 0 \\
\hline & & & PDI & n.o. & 80.3 & 5.7 & 23.7 \\
\hline & & & $\mathrm{PDA}$ & n.o. & 41.7 & 0 & 0 \\
\hline & & & PSS & n.o. & 63.3 & 3.6 & 12.5 \\
\hline \multirow[t]{4}{*}{15} & KU5859 & $\mathrm{P}$ & PPN & n.o. & 65.4 & 0 & 0 \\
\hline & & & PDI & n.o. & 81.5 & 0.9 & 8.5 \\
\hline & & & PDA & n.o. & 100.0 & 0 & 0 \\
\hline & & & PSS & n.o. & 31.7 & 3.3 & 9.3 \\
\hline \multirow[t]{4}{*}{16} & KU5860 & $\mathrm{P}$ & PPN & 13.1 & 0 & 0 & 0 \\
\hline & & & PDI & 49.3 & 37.9 & 1.8 & 2.4 \\
\hline & & & PDA & 8.3 & 0 & 0 & 0 \\
\hline & & & PSS & 14.1 & 11.4 & 1.6 & n.o. \\
\hline \multirow[t]{4}{*}{17} & KU5863 & $\mathrm{P}$ & PPN & 0.1 & 31.3 & 0 & 0 \\
\hline & & & PDI & 33.6 & 70.5 & 10.3 & 0.6 \\
\hline & & & PDA & 0 & 88.7 & 0 & 0 \\
\hline & & & PSS & 12.3 & 43.4 & 0.7 & 7.1 \\
\hline \multirow[t]{4}{*}{18} & KU5888 & $\mathrm{P}$ & PPN & 0.2 & 95.5 & 0 & 0 \\
\hline & & & PDI & 32.1 & 97.2 & 1.1 & 27.2 \\
\hline & & & $\mathrm{PDA}$ & 0 & 88.9 & 0 & 0 \\
\hline & & & PSS & 31.7 & 64.4 & 10.7 & 19.8 \\
\hline \multirow[t]{4}{*}{19} & KU5896 & $\mathrm{P}$ & PPN & n.o. & 66.9 & 0 & 0 \\
\hline & & & PDI & n.o. & 82.5 & 7.6 & 2.2 \\
\hline & & & $\mathrm{PDA}$ & n.o. & 100.0 & 0 & 0 \\
\hline & & & PSS & n.o. & 48.3 & 2.2 & 3.4 \\
\hline \multirow[t]{4}{*}{20} & KU12165 & $\mathrm{P}$ & PPN & 10.3 & 1.5 & 0 & 0 \\
\hline & & & PDI & 55.0 & 40.7 & 2.6 & 25.7 \\
\hline & & & PDA & 6.7 & 0 & 0 & 0 \\
\hline & & & PSS & 19.1 & 31.3 & 3.2 & 16.5 \\
\hline
\end{tabular}

PMCs observed.

Pollen fertility. Anthers of all of the parental accessions and the four Testers were normally dehisced at anthesis. The PPN was very high, ranging from 71.8 to 98.7. Three estimates representing pollen fertility studied in the $\mathrm{F}_{1}$ 's are shown in Tables 1,2 and 3. They varied widely among cross combinations. The PPN, PDI and PDA ranged from 0 to $96.3,0$ to 97.2 and 0 to 100 , respectively, and they correlated significantly with one another (Table 4). Furthermore, distinct correlation was observed, as mentioned below, between the pollen fertility of the $F_{1}$ 's and the geographical regions where the parental accessions were collected.

(a) The Aegean islands. The $\mathrm{F}_{1}$ 's between all of the nine accessions from the Aegean islands and Tester A showed drastically low pollen fertility (Table 1). The
PPN ranged from 0 to 0.1 and the anthers never dehisced $(\mathrm{PDA}=0)$. All the $\mathrm{F}_{1}$ 's between Tester $\mathrm{B}$ and the Aegean accessions except one from Site 7 showed almost complete sterility. The $F_{1}$ involving the accession from Site 7 showed slightly higher pollen fertility $(\mathrm{PPN}=15.1)$. The $\mathrm{F}_{1}$ between this accession and Tester $\mathrm{C}$ showed a PPN as high as 42.6 and the PDA was 71.4. In addition, the $\mathrm{F}_{1}$ 's between Tester $\mathrm{C}$ and the accessions from Sites 2 and 8 were partially fertile, PPN's being 14.5 and 8.9, respectively. However, the $\mathrm{F}_{1}$ 's between the other six accessions and Tester $\mathrm{C}$ showed almost complete sterility. In contrast to these hybrids, the $\mathrm{F}_{1}$ 's between six of the nine Aegean accessions and Tester D showed a high pollen fertility, with the PPN ranging from 56.0 to 96.3 and the PDA ranging from 66.7 to 100 . The $\mathrm{F}_{1}$ involving the accession from Site 1 was partially fertile (PPN = 25.0). The $F_{1}$ 's between all of the four Testers and the accessions from Sites 6 and 9 were highly sterile. 
Table 3. The estimates of pollen and seed fertility in the $\mathrm{F}_{1}$ hybrids between the four Testers and the 15 accessions of Ae. caudata from South Anatolia, East Anatolia and northern Iraq. For the abbreviations of estimates and varieties, see Table 1

\begin{tabular}{|c|c|c|c|c|c|c|c|}
\hline \multirow{2}{*}{$\begin{array}{l}\text { Site } \\
\text { No. }\end{array}$} & \multirow{2}{*}{$\begin{array}{l}\text { Accession } \\
\text { No. }\end{array}$} & \multirow[b]{2}{*}{ Var. } & \multirow{2}{*}{$\begin{array}{l}\text { Esti- } \\
\text { mates }\end{array}$} & \multicolumn{4}{|c|}{ Testers } \\
\hline & & & & $\mathrm{A}$ & B & $\mathrm{C}$ & $\mathrm{D}$ \\
\hline $\begin{array}{l}\text { Soutl } \\
21\end{array}$ & $\begin{array}{l}\text { natolia } \\
\text { KU5867 }\end{array}$ & $\mathrm{P}$ & $\begin{array}{l}\text { PPN } \\
\text { PDI } \\
\text { PDA } \\
\text { PSS }\end{array}$ & $\begin{array}{l}14.1 \\
52.4 \\
10.0 \\
52.3\end{array}$ & $\begin{array}{l}28.9 \\
60.9 \\
61.1 \\
51.8\end{array}$ & $\begin{array}{l}0 \\
6.8 \\
0 \\
8.7\end{array}$ & $\begin{array}{c}0 \\
11.4 \\
0 \\
8.1\end{array}$ \\
\hline 22 & KU5897 & $\mathrm{P}$ & $\begin{array}{l}\text { PPN } \\
\text { PDI } \\
\text { PDA } \\
\text { PSS }\end{array}$ & $\begin{array}{r}62.5 \\
86.3 \\
100.0 \\
65.1\end{array}$ & $\begin{array}{c}0 \\
42.1 \\
0 \\
28.4\end{array}$ & $\begin{array}{l}\text { n.o. } \\
\text { n.o. } \\
\text { n.o. } \\
\text { n.o. }\end{array}$ & $\begin{array}{l}\text { n.o. } \\
\text { n.o. } \\
\text { n.o. } \\
\text { n.o. }\end{array}$ \\
\hline 23 & KU5899 & $\mathrm{P}$ & $\begin{array}{l}\text { PPN } \\
\text { PDI } \\
\text { PDA } \\
\text { PSS }\end{array}$ & $\begin{array}{r}93.3 \\
96.9 \\
100.0 \\
80.0\end{array}$ & $\begin{array}{r}0.5 \\
47.6 \\
10.0 \\
58.9\end{array}$ & $\begin{array}{l}0 \\
4.5 \\
0 \\
5.1\end{array}$ & $\begin{array}{r}3.5 \\
26.6 \\
3.3 \\
18.5\end{array}$ \\
\hline $\begin{array}{l}\text { East } \\
24\end{array}$ & $\begin{array}{l}\text { atolia } \\
\text { KU5484 }\end{array}$ & $\mathrm{P}$ & $\begin{array}{l}\text { PPN } \\
\text { PDI } \\
\text { PDA } \\
\text { PSS }\end{array}$ & $\begin{array}{l}24.2 \\
56.9 \\
36.7 \\
50.0\end{array}$ & $\begin{array}{c}0 \\
23.2 \\
0 \\
39.7\end{array}$ & $\begin{array}{l}0 \\
5.4 \\
0 \\
1.4\end{array}$ & $\begin{array}{c}0 \\
23.6 \\
0 \\
13.8\end{array}$ \\
\hline 25 & KU5485 & $\mathrm{T}$ & $\begin{array}{l}\text { PPN } \\
\text { PDI } \\
\text { PDA } \\
\text { PSS }\end{array}$ & $\begin{array}{c}0 \\
33.1 \\
0 \\
41.0\end{array}$ & $\begin{array}{r}61.0 \\
86.7 \\
100.0 \\
43.1\end{array}$ & $\begin{array}{l}0 \\
7.5 \\
0 \\
4.1\end{array}$ & $\begin{array}{c}0 \\
19.5 \\
0 \\
32.1\end{array}$ \\
\hline 26 & KU5489 & $\mathrm{T}$ & $\begin{array}{l}\text { PPN } \\
\text { PDI } \\
\text { PDA } \\
\text { PSS }\end{array}$ & $\begin{array}{l}27.0 \\
67.9 \\
96.7 \\
55.6\end{array}$ & $\begin{array}{l}19.3 \\
62.6 \\
66.7 \\
39.3\end{array}$ & $\begin{array}{l}0 \\
3.1 \\
0 \\
3.8\end{array}$ & $\begin{array}{c}0 \\
15.4 \\
0 \\
18.7\end{array}$ \\
\hline 27 & KU5490 & $\mathrm{P}$ & $\begin{array}{l}\text { PPN } \\
\text { PDI } \\
\text { PDA } \\
\text { PSS }\end{array}$ & $\begin{array}{l}69.7 \\
90.2 \\
87.5 \\
61.2\end{array}$ & $\begin{array}{r}9.4 \\
41.3 \\
5.6 \\
59.8\end{array}$ & $\begin{array}{c}0 \\
10.2 \\
0 \\
6.2\end{array}$ & $\begin{array}{l}0 \\
9.7 \\
0 \\
2.8\end{array}$ \\
\hline 28 & KU5491 & $\mathrm{P}$ & $\begin{array}{l}\text { PPN } \\
\text { PDI } \\
\text { PDA } \\
\text { PSS }\end{array}$ & $\begin{array}{r}95.3 \\
96.9 \\
100.0 \\
82.9\end{array}$ & $\begin{array}{l}17.2 \\
58.6 \\
33.3 \\
50.2\end{array}$ & $\begin{array}{l}0 \\
4.7 \\
0 \\
6.3\end{array}$ & $\begin{array}{c}0 \\
12.5 \\
0 \\
6.3\end{array}$ \\
\hline 29 & KU5492 & $\mathrm{P}$ & $\begin{array}{l}\text { PPN } \\
\text { PDI } \\
\text { PDA } \\
\text { PSS }\end{array}$ & $\begin{array}{r}75.4 \\
91.4 \\
100.0 \\
54.9\end{array}$ & $\begin{array}{l}19.1 \\
59.4 \\
66.7 \\
74.2\end{array}$ & $\begin{array}{l}0 \\
4.8 \\
0 \\
0.7\end{array}$ & $\begin{array}{c}0 \\
12.1 \\
0 \\
8.3\end{array}$ \\
\hline 30 & KU5885 & $\mathrm{T}$ & $\begin{array}{l}\text { PPN } \\
\text { PDI } \\
\text { PDA } \\
\text { PSS }\end{array}$ & $\begin{array}{l}65.9 \\
83.3 \\
96.7 \\
83.6\end{array}$ & $\begin{array}{l}11.9 \\
62.7 \\
33.3 \\
43.3\end{array}$ & $\begin{array}{l}0 \\
7.5 \\
0 \\
\text { n.o. }\end{array}$ & $\begin{array}{l}0 \\
8.9 \\
0 \\
5.6\end{array}$ \\
\hline 31 & KU5889 & $\mathrm{P}$ & $\begin{array}{l}\text { PPN } \\
\text { PDI } \\
\text { PDA } \\
\text { PSS }\end{array}$ & $\begin{array}{l}81.3 \\
90.1 \\
96.7 \\
70.7\end{array}$ & $\begin{array}{c}0.4 \\
38.7 \\
0 \\
53.7\end{array}$ & $\begin{array}{c}0 \\
\text { n.o. } \\
0 \\
\text { n.o. }\end{array}$ & $\begin{array}{c}0 \\
17.5 \\
0 \\
17.6\end{array}$ \\
\hline 32 & KU5891 & $\mathrm{T}$ & $\begin{array}{l}\text { PPN } \\
\text { PDI } \\
\text { PDA } \\
\text { PSS }\end{array}$ & $\begin{array}{r}7.5 \\
62.4 \\
16.7 \\
39.0\end{array}$ & $\begin{array}{r}54.3 \\
85.2 \\
100.0 \\
54.6\end{array}$ & $\begin{array}{c}0 \\
16.4 \\
0 \\
2.6\end{array}$ & $\begin{array}{c}0 \\
17.9 \\
0 \\
17.8\end{array}$ \\
\hline $\begin{array}{l}\text { Nortl } \\
33\end{array}$ & $\begin{array}{l}\text { n Iraq } \\
\text { KU5475 }\end{array}$ & $\mathrm{P}$ & $\begin{array}{l}\text { PPN } \\
\text { PDI } \\
\text { PDA }^{a)} \\
\text { PSS }\end{array}$ & $\begin{array}{c}72.8 \\
91.3 \\
+ \\
70.0\end{array}$ & $\begin{array}{c}43.0 \\
75.4 \\
+ \\
50.0\end{array}$ & $\begin{array}{c}0 \\
12.9 \\
\overline{3} .1\end{array}$ & $\begin{array}{c}0 \\
14.7 \\
\overline{21.2}\end{array}$ \\
\hline 34 & KU5472 & $\mathrm{T}$ & $\begin{array}{l}\text { PPN } \\
\text { PDI } \\
\text { PDA } \\
\text { PSS }\end{array}$ & $\begin{array}{l}66.2 \\
86.5 \\
91.7 \\
65.7\end{array}$ & $\begin{array}{r}6.0 \\
48.6 \\
4.2 \\
35.0\end{array}$ & $\begin{array}{l}0 \\
7.2 \\
0 \\
7.3\end{array}$ & $\begin{array}{c}0.2 \\
28.2 \\
0 \\
\text { n.o. }\end{array}$ \\
\hline 35 & KU5482 & $\mathrm{P}$ & $\begin{array}{l}\text { PPN } \\
\text { PDI } \\
\text { PDA } \\
\text { PSS }\end{array}$ & $\begin{array}{r}34.0 \\
76.4 \\
100.0 \\
70.2\end{array}$ & $\begin{array}{r}4.1 \\
49.4 \\
25.0 \\
46.6\end{array}$ & $\begin{array}{l}0 \\
8.7 \\
0 \\
5.6\end{array}$ & $\begin{array}{c}0 \\
30.0 \\
0 \\
12.0\end{array}$ \\
\hline
\end{tabular}

\footnotetext{
a) +: anther normally dehiscent, -: anther indehiscent.
} 
Table 4. Correlation coefficients among the estimates of pollen and seed fertility

\begin{tabular}{cccc}
\hline \hline Estimates & PPN & PDI & PDA \\
\hline PDI & 0.884 & & \\
PDA & 0.895 & 0.888 & \\
PSS & 0.786 & 0.825 & 0.766 \\
\hline
\end{tabular}

(b) West Anatolia. All the $\mathrm{F}_{1}$ 's involving Testers A and $\mathrm{B}$ were almost completely sterile (Table 1). For the two accessions from Sites 10 and 12 , the $\mathrm{F}_{1}$ 's involving Tester $\mathrm{D}$ showed the highest fertility and those involving Tester C followed them. For the accession from Site 11, the $\mathrm{F}_{1}$ involving Tester $\mathrm{C}$ showed the highest fertility and that with Tester $\mathrm{D}$ gave the second highest.

(c) Central Anatolia. In contrast to the Aegean and the West Anatolian accessions, the $\mathrm{F}_{1}$ 's between all of the eight Central Anatolian accessions and Testers $\mathrm{C}$ and $\mathrm{D}$ were completely sterile (Table 2 ). For Tester $\mathrm{B}$, the $\mathrm{F}_{1}$ 's involving the accessions from three sites (Sites 15, 18 and 19) showed a high pollen fertility, the PPN ranging from 65.4 to 95.5. The $F_{1}$ 's involving the three accessions from Sites 13,14 and 17 showed partial pollen fertility whose PPN ranged from 17.8 to 51.8. The other two accessions from Sites 16 and 20 produced almost completely sterile $\mathrm{F}_{1}$ 's when crossed with Tester B, the PPN being 0 and 1.5, respectively. For Tester A, three accessions from Sites 13,17 and 18 produced almost completely sterile $\mathrm{F}_{1}$ 's whose PPN was 0 to 0.2 and the PDA was 0 . The other two accessions from Sites 16 and 20 produced partially fertile $\mathrm{F}_{1}$ 's, the PPN being 13.1 and 10.3 , respectively.

\section{(d) South Anatolia, East Anatolia and northern}

Iraq. The accessions from South Anatolia, East Anatolia and northern Iraq showed similar results in the fertility of the $F_{1}$ 's (Table 3). The $F_{1}$ 's from the crosses of all of the accessions, except one from Site 23, with Testers C and D were completely or almost completely sterile, the PPN being 0 or 0.2 and the PDA being 0 . The $\mathrm{F}_{1}$ between the accession from Site 23 and Tester D showed slightly higher fertility but its PPN was as low as 3.5. For Tester A, the $\mathrm{F}_{1}$ 's involving nine accessions (Sites 22, 23, 27 to 31, 33 and 34) showed normal or almost normal anther dehiscence and high PPN values ranging from 62.5 to 95.3. The $\mathrm{F}_{1}$ 's between Tester $\mathrm{A}$ and the accessions from Sites 26 and 35 also showed normal or almost normal anther dehiscence in spite of a PPN as low as 27.0 and 34.0 , respectively. The PDI values of those hybrids were 67.9 and 76.4 , indicating that abnormal pollen grains developed in almost normal stages. The $\mathrm{F}_{1}$ 's between Tester B and three (Sites 22, 23 and 31) of the above 11 accessions were completely or almost completely sterile. Those between the other eight accessions and Tester B were partially fertile, whose PPN ranged from 4.1 to 43.0 and the PDA was 0 or 10.0. The accession from Site 21 produced partially fertile $\mathrm{F}_{1}$ 's when crossed with Testers $\mathrm{A}$ and B. For the accession from Site 24, the $\mathrm{F}_{1}$ involving Tester A was partially fertile while that involving Tester $\mathrm{B}$ was completely sterile. The $\mathrm{F}_{1}$ 's between the accessions from Sites 25 and 32 and Tester B showed high pollen fertility and normal anther dehiscence. When crossed with Tester A, the former produced a sterile $\mathrm{F}_{1}$ while the latter produced a partially fertile $\mathrm{F}_{1}$.

Seed set after open-pollination. The percentage seed set after open-pollination (PSS) in the parental lines including the four Testers ranged from 52.0 to 97.9. The PSS in the $\mathrm{F}_{1}$ 's ranged from 0 to 91.5 (Tables 1,2 and 3). It significantly correlated with the three estimates for pollen fertility $(\mathrm{p}<0.01)$, especially with the PDI (Table 4).

\section{DISCUSSION}

Correlation among the estimates for pollen and seed fertility. Three estimates were adopted for pollen fertility in the present study, and they closely correlated with one another. High correlation between pollen normality (PPN or PDI) and anther dehiscence (PDA) suggests that the anther indehiscence observed in the sterile $\mathrm{F}_{1}$ 's might be due to pollen abnormality, i. e., the low percentage of normal pollen grains in the anthers. Close correlation between seed set (PSS) and pollen fertility suggests that the degree of embryo-sac abortion was similar to that in the pollen grains. Among the three estimates of pollen fertility, the PDI correlated most closely with the PSS. This suggests the possibility that moderately aborted embryo-sacs maintained the ability to be fertilized and to develop plump endosperms. An anatomical study of the embryo-sac of the $\mathrm{F}_{1}$ 's is necessary for precisely elucidating the development of the female gametophytes in the $\mathrm{F}_{1}$ 's.

Geographical differentiation in Ae. caudata. Tanaka et al. (1967) was the first to find the intraspecific hybrid sterility in Ae. caudata and they concluded that the sterility is characteristic to intervarietal hybrids. The two varieties that they used were collected from different geographical regions. Ohta (1992) found that $F_{1}$ hybrids between the two varieties originating in sympatric stands on the Aegean islands are fully fertile. Furthermore, he crossed 10 accessions from the Aegean islands and Iraq with the four Testers and concluded that intraspecific hybrid sterility in Ae. caudata does not correlate with the taxonomic variety but with the geographical area where the parental lines were collected. In the present study, 25 additional accessions collected from Anatolia and northern Iraq were crossed with the four Tester strains. The results confirmed the previous conclusion as discussed 
below.

(a) No relation between taxonomic varieties and hybrid sterility. Two varieties were taxonomically described in Ae. caudata based on the spike morphology (Eig, 1929). One is var. typica with an awn on the empty glumes of only the apical spikelet, and the other is var. polyathera with an awn on the empty glumes of both apical and lateral spikelets. Among the four Testers, only Tester B belonged to var. polyathera and the others to var. typica (Table 1). The three West Anatolian accessions belonged to var. typica. All of the $\mathrm{F}_{1}$ 's between them and Tester A were sterile while those involving Testers $\mathrm{C}$ and $\mathrm{D}$ were at least partially fertile. Variety polyathera occurs exclusively in Central Anatolia, and the $\mathrm{F}_{1}$ 's between Central Anatolian accessions and Tester A or B were fertile. The three South Anatolian accessions also belonged to var. polyathera. However, two of them produced fertile $\mathrm{F}_{1}$ 's when crossed with Tester A belonging to var. typica. The 12 accessions from East Anatolia and northern Iraq produced fertile $\mathrm{F}_{1}$ 's when crossed with Tester A and/or B irrespective of the variety. These results clearly indicate that the fertility of the $F_{1}$ 's is not correlated with the taxonomic variety of the parental lines.

(b) Correlation between geography and hybrid sterility. Many accessions from the Aegean islands and West Anatolia produced at least partially fertile $F_{1}$ 's when crossed with Testers $\mathrm{C}$ and $\mathrm{D}$, while they produced highly sterile $\mathrm{F}_{1}$ 's when crossed with Testers A and B (Table 1). On the contrary, many of the Central, South and East Anatolian and Iraqi accessions produced fertile $\mathrm{F}_{1}$ 's when crossed with Testers A and B, but no accession produced fertile hybrids involving Testers $\mathrm{C}$ and D (Tables 2 and 3). The accession from Site 7 was the only exception in producing fertile $\mathrm{F}_{1}$ 's when crossed with the three Testers $\mathrm{B}, \mathrm{C}$ and D. These results confirm the previous conclusion (Ohta, 1992) that the fertility of the $\mathrm{F}_{1}$ 's correlates with geographical area where the parental accessions occurred, and that the present distribution area of $A e$. caudata is divided into two geographical regions based on intraspecific hybrid sterility. Furthermore, based on the results from the present Tester crosses using the 25 additional accessions from Anatolia and Iraq, the two geographical regions were more precisely determined. Davis (1965) divided Turkey into six geographical divisions based on topography. The two geographical regions defined from the hybrid sterility coincide with Davis' divisions. The western region is composed of Greece and West Anatolia, and the eastern region consists of Central Anatolia, South Anatolia, East Anatolia and northern Iraq. The boundary between the two geographical regions is the mountainous region lying between West Anatolia and Central Anatolia (Fig. 1). The border region consisting of mountains higher than $1000 \mathrm{~m}$ may be an effective geographical barrier preventing gene flow between the western and the eastern regions, because $A e$. caudata is predominantly a lowland species occurring below $1000 \mathrm{~m}$ above sea level (Hodgkin et al., 1992; Slageren, 1994). In addition to this major division into the two geographical regions, some minor genetic differentiation can be recognized within each geographical region. Within the western region, most of the accessions derived from the southern Aegean islands (Sites 1 to 5) produced sterile $\mathrm{F}_{1}$ 's when crossed with Tester $\mathrm{C}$, while those from West Anatolia and the northwestern Aegean islands adjacent to West Anatolia (Sites 7 to 12) produced partially fertile $\mathrm{F}_{1}$ 's. In addition, two accessions (Sites 6 and 9) produced only sterile $F_{1}$ 's when crossed with all of the Tester strains. These results suggest that the western region of the distribution can be further subdivided into at least two additional regions. In the eastern region, many Central Anatolian accessions produced $\mathrm{F}_{1}$ 's that showed the highest fertility when crossed with Tester B, while most of the South Anatolian, the East Anatolian and the northern Iraqi accessions produced the $\mathrm{F}_{1}$ 's with the highest fertility when crossed with Tester A. This also suggests that the eastern region of the distribution can be subdivided into Central Anatolia and the more southern regions.

Post-glacial establishment of the geographical distribution in Ae. caudata. Sakamoto (1973) grouped the 16 genera of the tribe Triticeae Dum. into the Arctictemperate group and the Mediterranean group, based on the geographical distribution and ecological characteristics. The latter consists mainly of annual genera and the former of perennial genera. The latter group, to which the genus Aegilops belongs, was thought to be differentiated from the former group as the Mediterranean climate became established in the Quaternary (Sakamoto, 1973). The Quaternary is characterized by having several glacial periods. The geographical distribution of Aegilops and wild Triticum species was greatly affected by climatic changes during the glacial and interglacial periods. For elucidating not only the specific and intraspecific differentiation but also the establishment of the present geographical distribution of the genus Aegilops, it is important to take into consideration the shift in geographical distribution during the last glacial period. Recent palaeopalynological studies in the Near East allow us to reconstruct the shift in the geographical distribution of plant species in the late Quaternary. Van Zeist and Bottema (1991) presented a visual overview of the geographical shift in vegetation in the late Pleistocene and Holocene. In the period from $18000 \mathrm{BP}$ to $16000 \mathrm{BP}$, the temperature dropped to a minimum, and steppe and desert-steppe with Artemisia and Chenopodiaceae covered the greater part of the Near East, which is now the pri- 
mary diversity center of the wild Triticum and Aegilops species. As the climate became warmer, the woodland and forest-steppe zone, the habitats of wild wheat, expanded considerably. In the early Holocene, $8000 \mathrm{BP}$, the woodland and forest-steppe zone gradually spread into the inland areas of the Anatolian Plateau from the western Levant or the sheltered habitats in the East Taurus / Zagros mountains arc such as the Ruwandiz area in northern Iraq (van Zeist and Bottema, 1991). Hillman (1996) reconstructed the spread of wild einkorn across the northern Fertile Crescent based on the vegetation maps by van Zeist and Bottema (1991), and suggested that wild einkorn penetrated into the central Anatolian Plateau from the northeastern corner of the Mediterranean basin after the last glacial period.

The present study on intraspecific hybrid sterility revealed that the present geographical distribution of Ae. caudata is clearly divided into the two geographical regions. The establishment of the geographical distribution of Ae. caudata can be reconstructed based on the present results and the vegetation maps by van Zeist and Bottema (1991). In the maximum glacial period from $18000 \mathrm{BP}$ to $16000 \mathrm{BP}$, Ae. caudata did not occur in Central and East Anatolia, and its distribution area was geographically divided into the two isolated regions. One was the region surrounding the Aegean Sea where the climate was affected by the sea and was not excessively cold or dry, and the other was the western Levant or some sheltered habitats in the East Taurus / Zagros mountains arc. As the climate became warmer, Ae. caudata migrated into Central and East Anatolia with the spread of oak woodland from the latter region, and now occupies the eastern region of the distribution. On the other hand, the western region of the present distribution was established by populations that occurred in the Aegean Sea region during the last glacial period.

Ohta (1995) suggested that intraspecific hybrid sterility in Ae. caudata is caused by cryptic structural hybridity defined as a chromosomal sterility due to heterozygosity for structural differences so small as not to materially influence chromosome pairing at MI (Stebbins, 1945). This mechanism causing hybrid sterility between the western and the eastern regions may have evolved during the last glacial period at the latest, and geographical isolation promoted intraspecific genetic differentiation. In the process of migration after the last glacial period, the chromosome structure of Ae. caudata continues to change, resulting in subdivision within each distribution region. Thus, Ae. caudata is thought currently to be in the process of speciation. Further studies of intraspecific differentia- tion in Ae. caudata will give us a key to elucidating how the speciation occurred, and continues to occur, in the diploid wheat group.

The author thanks the Plant Germ-plasm Institute, Kyoto University, Japan, for kindly providing the material.

\section{REFERENCES}

Bor, N. L. (1968) Gramineae. In: Flora of Iraq 9. (eds.: C. C. Townsend, E. Guest, and A. Al-Rawi), pp. 1-588. Ministry of Agriculture, Republic of Iraq, Bagdad.

Bor, N. L. (1970) Gramineae-Triticeae. In: Flora Iranica 70. (ed.: E. H. Rechinger), pp. 147-244. Academische Drucku.Verlagsanstalt, Graz.

Davis, P. H. (1965) Flora of Turkey and the East Aegean Islands 1, pp. 567. Edinburgh Univ. Press, Edinburgh.

Eig, A. (1929) Monographisch-Kritische Übersicht der Gattung Aegilops. Repert. Spec. Nov. Regni Veg. 55 , 1-228.

Hammer, K. (1980) Vorarbeiten zur monographischen Darstellung von Wildpflanzensortimenten: Aegilops L. Kulturpflanze 28, 33-180.

Hillman, G. (1996) Late Pleistocene changes in wild plant-foods available to hunter-gatherers of the northern Fertile Crescent: possible preludes to cereal cultivation.In: The Origins and Spread of Agriculture and Pastoralism in Eurasia (ed.: D. R. Harris), pp. 159-203. Smithsonian Institution Press, Washington, D. C.

Hodgkin, T., Adham, Y. J., and Powell, K. S. (1992) A preliminary survey of wild Triticum and Aegilops species in the world's genebanks. Hereditas 116, 155-162.

Ohta, S. (1992) Intraspecific hybrid sterility in Aegilops caudata L. Hereditas 116, 247-251.

Ohta, S. (1995) Cytogenetic evidence for cryptic structural hybridity causing intraspecific hybrid sterility in Aegilops caudata L. Jpn. J. Genet. 70, 355-364.

Rechinger, K. H. (1943) Flora Aegaea. Denkschr. Akad. Wiss. Wien, Math-Nat. Kl. 105, 1-924.

Sakamoto, S. (1973) Patterns of phylogenetic differentiation in the tribe Triticeae. Seiken Ziho 24, 11-31.

Sakamoto, S. (1986) A preliminary report of Kyoto University ethnobotanical exploration to Greece and Turkey in 1982, pp. 73. Rep. Plant Germ-plasm Inst., Kyoto Univ. 7, Kyoto.

Slageren, M. W. van (1994) Wild wheats: a monograph of Aegilops L. and Amblyopyrum (Jaub. \& Spach) Eig, pp. 512. Agricultural University, Wageningen.

Stebbins, G. L. (1945) The cytological analysis of species hybrids. II. Bot. Rev. 11, 463-486.

Tanaka, M. (1983) Catalogue of Aegilops-Triticum germ-plasm preserved in Kyoto University, pp. 179. Plant Germ-plasm Institute, Kyoto Univ., Kyoto.

Tanaka, M., Suemoto, H., and Ichikawa, S. (1967) The awn characters and sterility in Aegilops caudata L., I. Jap. J. Breed. 17, Suppl. 2, 155-156.

van Zeist, W. and Bottema, S. (1991) Late Quaternary vegetation of the Near East. Beihefte zum Tübinger Atlas des Vorderen Orients, Reihe A, 18, 1-156. 